\title{
Boulding's Psychic Capital: The Linking of Individual and Collective Identities
}

\author{
William Walter Bostock* \\ *University of Tasmania
}

Submitted 27 March 2020 Accepted 7 July 2020 Published 2 December 2021

\begin{abstract}
The purpose of this article is to establish that Kenneth E. Boulding, an economist whose work also encompassed many other disciplines, provided a valuable insight within the study of psychology. Boulding observed that while in an economic unit there is a store of financial capital which is necessary for continued existence, also in human nature there is a need for a reserve of psychic capital that is vital for the mental health of the individual and society. Psychic capital does this by providing a link consisting of positive feelings shared between the individual and the larger grouping. Boulding proposed that a coherent body of thoughts, memories and emotions may be shared between individual and collective minds as shared psychic capital. Finally, some present-day examples are given whereby the consequences of a loss of psychic capital have been observed with particular emphasis on collective depression and suicide.
\end{abstract}

Keywords: depression; identity; psychic capital; social alienation

\section{Introduction}

Kenneth E Boulding (1910-1993) was an English-born naturalised American economist who achieved recognition for his concepts of system, homeostasis and isomorphism between economy and social system. He was also active at the practical level in promoting world peace and sustainability. One of his economic concepts of particular interest to those focussed on psychology was that of psychic capital. In economics, capital is traditionally understood to be an accumulation of wealth, but Boulding took this further to see that capital can also be an accumulation of memories of desirable mental states which he called psychic capital. This phenomenon may be transitory in nature because of the ever-present process of entropy. When at the collective level, positive memories and emotions constitute psychic capital, which is an essential element in maintaining the continued existence of a community, particularly under conditions of extreme stress such as war, pandemic or famine. In isomorphism with an economic unit, Boulding observed that an individual requires a store of psychic capital to sustain themself with a reserve of positive mental states which could be memories of pleasure, success, achievement, recognition and tradition. He further added that in the same way, a whole society needs a store of psychic capital to sustain itself and even continue to exist (Boulding, 1950). Positive psychic capital could consist of the awareness, celebration and memory of achievement, which could be scientific,

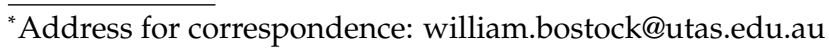




\section{Bostock || Boulding's Psychic Capital}

sporting, major projects, material living standard or any one of the activities which go into making communal identity.

The desire to add to psychic capital can be a powerful motivating force amongst political leaders, and in the process of seeking to ensure continued existence, there will be exchanges involving increases or decreases of psychic capital, either through decision, the turn of events or natural entropic process (Boulding, 1950). However, fear, insecurity and terror, memories of failures, disasters, atrocities, or perceived injustices and indignities (as either recipient or perpetrator) can lead to a cumulative depletion of psychic capital, all of which may represent a burden not unlike a collapse-inducing burden of financial debt. Loss of psychic capital and fear of further depletion can thus be a powerful motivating factor to those affected. As Boulding stated, "a society which loses its identity with posterity and which loses its positive image of the future loses also its capacity to deal with present problems, and soon falls apart." (Boulding, 1966). Thus, as has been noted by Horvath, the mere existence of psychic wealth is a question that poses a challenge for transdisciplinary approaches (Horvath, 2000).

\section{Discussion}

\section{Identity}

The concept of identity has, for a long-time concerned philosophers, theologians, medical scientists, mathematicians, and social scientists of many subdisciplines without a final consensus ever being achieved. In the approach of psychoanalysis as pioneered by Freud, identity was seen as the basis of the socialisation process by which individuals are moulded, which is reflected by the statement that identification is seen by psychoanalysis as an early expression of an emotional tie with another person (Freud, 1955). To Freud, identification was a developmental process by which a child would perceive themself through interaction with a parent. This theme was developed by the identity theorist Erikson who asserted that a strong sense of identity is a fundamental part of both a successfully functioning individual and for a society thus bringing to light the concept of the collective mental state. He also observed that in a collectivity, the states of confusion, crisis and panic are created by a weak or confused sense of identity. Erikson went on to state that when identity is not well-integrated, strongly negative emotions may emerge, which, in his view, may arouse an irrational hatred of 'otherness' (Erikson, 1968).

In more modern times, a conceptualisation of identity proposes a mental state of continuous, internal, subjective awareness (Reber, 1995), which may occur in either an individual or as a group, community or larger collectivity. One can expand further by noting that a robust and well-integrated sense of identity is essential to successful functioning and continued existence (Puri B.K; Laking, 1996). A theory of social identity has been developed by Tajfel et al. (1979) whereby an individual identity has a social dimension based on group membership, in a process which creates in-groups and out-groups, leading to negative thoughts and conflict the connection between collective behaviour and intergroup aggression has been explored by Faturochman (1999).

The contribution of Boulding to the understanding of the concept of identity was in proposing 


\section{Bostock || Boulding's Psychic Capital}

that psychic capital is in fact the essence of identity, in other words a reserve of good feelings that make survival possible. Moreover, this provides a link between the individual and the collective through the notion of collective identity. There has been much work about collective identity. It may be argued that many novelists and other artists have expressed their feelings of their identity throughout their work. Some prominent examples include the great Spanish writer Cervantes, the romantic poet Adam Mickiewicz who gave rise to a new form to Polish identity, and the writer and political activist Jose Riza, who powerfully formed Philippine identity, particularly after his death. Karl Marx used a form of identity theory when he conceptualised class consciousness, and many political leaders of all ideological positions have attempted to create and exploit collective identity amongst the governed individuals.

Collective identity is a multifaceted concept which exists at a subjective level as morale, esprit de corps, or in-group feelings of affection such as brotherhood or sisterhood and can be based on narrative or legend as seen in indigenous populations. One can visualise collective identity as: a process of collective self-awareness; possession of boundaries; belief in continuity in space and time; the act of being in communication both internally and externally; transacting with the internal and external world with self-awareness; self-appraisal of performance; possessing a feeling of responsibility for actions carried out collectively and individually and holding others responsibility; with the result being successful adaptation and survival (Brewster Smith, 1985). National identity, a political example of collective identity has been studied by anthropologists in the form of "national character". Political scientists have often emphasised the importance of national identity to achieve state stability, especially in post-colonial nation-states. The concepts of national identity and state stability are conceptually analogous to the mind/body relationship, in that a strong sense of national identity is a necessary condition of a state that is facing a threat (Bostock \& Smith, 2001). In Boulding's conceptualisation, identity is based in memory therefore the possession of memories and emotions that can be drawn upon is a requirement of a mental state in a similar way that capital is in an economic context at a collective level as well as an individual level.

\section{Psychic Capital and the Sense of Coherence}

The importance of the integration of the sense of identity was underlined by Antonovsky with the development of his concept of the sense of coherence. Furthermore, Antonovsky saw a key role of an individual's sense of coherence in the maintenance of health. The sense of coherence is defined as a "global orientation that expresses the extent to which one has a pervasive, enduring through dynamic feeling of confidence that one's internal and external environments are predictable and that there is a high probability that things will work out as well as can be reasonably expected." (Antonovsky, 1980).

The concept of sense of coherence is also exhibited at a collective level whenever a sense of group consciousness exists (Antonovsky, 1980), and this embodies Boulding's psychic capital which has internal integration. Within the sense of coherence, Boulding's concept of psychic capital has further relevance. Boulding's psychic capital provides integration to the sense of identity at both the individual level and the collective level, thus securing the "morale, legitimacy and the 'nerve' of society" (Boulding, 1966). Furthermore, Eriksson and Lindstrom noted that under conditions of 


\section{Bostock || Boulding's Psychic Capital}

extreme stress, the sense of coherence can be severely compromised (Eriksson \& Lindström, 2006).

Identity Capital

A similar concept to psychic capital that has been proposed is identity capital, as developed by Cote, and which can be distinguished from the concepts of human capital and cultural capital. Cote concluded that identity capital gave an individual, particularly one possessing a "diversified portfolio", a store of resources enabling the handling of life's vagaries (CôTé, 1996). Psychic capital can thus be said to be an application of identity capital at the collective level.

\section{The Collective Mental State}

The existence of consciousness or mental state possessed by a group, crowd, community, nation or other collectivity, that is considered to be over and above the sum of individual consciousnesses, has long been asserted. In his classic work The Crowd, Le Bon (2008) observed that in crowds a collective mind can emerge by a process of contagion. Durkheim (1964) discussed in depth the concept of the collective consciousness and Halbwachs (1992) analysed the concept of the collective memory. Thus, one can refer to the emergence of a collective mental state (Bostock, 2002).

Against these formulations, there has been a long-standing denial that collective mental states exist, on the grounds that a mind requires a brain, and as a collective brain does not exist, a collective mind cannot exist. Therefore, all behaviour must be reduced to the behaviour and actions of individuals. The existence of genuinely collective emotions has been examined by philosophers. For example, Tollefsen argued that groups can be the legitimate bearers of mental states (Tollefsen, 2006), while Szanto has asserted that it is possible for a group of individuals to literally share a single mental unit, which he calls a zombie conception of the group mind (Szanto, 2014). Whilst the existence of an emergent collective mental state has not been definitively established, there remains considerable controversy about the matter. Furthermore, mental state is a term used to refer to the general condition of a mind, and the concept could be extended to refer particularly to mood or mental energy level, taking the form of a free will.

A related topic is whether genuinely collective emotions can exist, or whether shared emotions are simply aggregates. Huebner (2011) considered this question from a philosophical point of view and concluded that genuinely collective emotions can exist, given a certain level of organisation. This controversy is also part of psychiatric discourse. For example, the notion Folie à deux has been recognised since 1877 as an induced psychotic disorder, being a condition passed by contagion between two people such as siblings or spouses. It is difficult to improve upon Le Bon's description of the mechanism of transmission as contagion, on the analogy of a physical disease. To artists, writers and musicians, it is a familiar process, but in scientific investigation there is reduced understanding. However, in the Diagnostic and Statistical Manual of Mental Disorders (DSM-5) (APA, 2013), the Shared Psychotic Disorder (Folie à Deux) is not considered as a separate entity, leaving the diagnostician to classify the secondary patient as "Delusional Disorder" or "Other Specified Schizophrenic Spectrum and Other Psychotic Disorder". 


\section{Bostock || Boulding's Psychic Capital}

An interesting example of shared disorder was reported to have occurred in Brazil in a clinic which regularly deals with suicidality (Estellita-Lins et al., 2015). At this clinic, an unusual Christmas tree was installed by a team involved in work that was stressful at that time of year. The Christmas tree was unusual in that it put on display a Santa Claus in an act of suicide, which produced among participants and visitors a collective state of mind. This was such that they felt mutually involved but at the same time calmed, because of recognizing the presence of death at the time of Christmas celebration. It can thus be observed that all types of organizations have a level of psychological health, and the condition of that prevailing at any point is a collective mental state. Some ground-breaking research is currently investigating the neurobiology of interpersonal functioning using neuro-imaging. This approach is investigating the degree of similarity/dissimilarity of neural signals between multiple interacting brains. Using this technique, it will be possible to identify the neural correlates of a collective mental state. Thus, the current work of neuroscientists on the transmission of neuro-signals between individual brains is giving confirmation to the concept that psychic capital can be shared. Moreover, the communication of emotion is the most important process for the purpose of mental health (Ray et al., 2017).

\section{Psychic Capital and Collective Depression}

Depression is an example of a mental state, along with elation, paranoia, trauma, or grief, which may affect an individual, group, community, whole nation or any other collectivity. When depression affects a high proportion of the members of a collectivity it is characterized by a prevailing and seemingly permanent sense of inadequacy, despondency, lack of vitality, sadness and hopelessness (Fauziyyah \& Ampuni, 2018). While there is on-going debate over the philosophical status of the concept, some modern theorists treat collective depression as an aggregate of states of depressions among individuals. Kesner sees the insufficient grasp of the relationship between individual and collective mental pathologies as one of the major challenges of contemporary psychiatry. Here he highlights the role of public (material) representations in this process and observes that, for example, media amplification of traumatic disaster news generates anxiety symptoms, stress disorders, and other psychopathologies (Kesner, 2018).

There is also growing interest in the concept of mass sociogenic illness where a physical or psychological condition is observed to spread within a group in the absence of a shared organic cause. Collective depression is often found in detained communities, such as ghettos, asylum-seeker camps, concentration camps or other places where all prospects of release are extremely improbable and is recognizable by a high incidence of suicide (Macken, 2019).

\section{Collective Depression and Suicide}

Collective depression is present amongst persons deprived of liberty (PDL). In a study of inmates at Palawan Provisional Jail in the Philippines, (Artizona et al., 2019) it was observed that depression was associated with biological factors including a lack of hygiene, financial and physical problems. It was also found that psychological factors including preoccupation emotion, and social factors such 


\section{Bostock || Boulding's Psychic Capital}

as family issues, lack of friends, and maltreatment were all associated with higher rates of depression in this sample. Suicidal ideation was also present, and it was reported that three inmates completed suicide. A loss of psychic capital at both the individual and collective level may have been associated with the descriptions of mental state in this example.

In his study of Germany in the closing stages and immediate aftermath of World War II, the historian Huber discussed the town of Demmin, whose pre-war population had been around 15,000. By October 1945, 927 members of the population of Demmin had completed suicide. Expanding his focus to the whole of Germany, Huber identified an epidemic of suicide, where a large but unknown number of civilians had suicided. The associated factors in this population included loss of hope, fear and shame, followed by silence and an acceptance of the commission of atrocities. This, in Huber's view, became part of the German identity, which may be considered a dramatic depletion of psychic capital (Huber, 2019). A proposed treatment for collective depression is thus the restoration of psychic capital with a positive sense of coherence and an integration of positive beliefs and emotions. Collective depression can also be a state of considerable vulnerability, and strategies that later turn out to be destructive of psychic capital may be clutched at through misplaced belief in the efficacy of radical measures.

\section{Conclusion}

Boulding's significant contribution to psychology was the concept of psychic capital. Just as in an economic unit where a store of capital or positive wealth is necessary for continued existence, Boulding proposed that a store of psychic capital or positive feelings is necessary for the psychological continuity of the individual and for society. By giving a shared sense of coherence to identity, psychic capital provides a vital link between the individual and the collectivity. In this connection, Boulding emphasized that thoughts and emotions can be shared between individual minds and collective minds through shared psychic capital. Here the concept of psychic capital is relevant as it represents the accumulation of material transmitted by a process of contagion. Lastly, some examples are given where consequences of loss of psychic capital are observed, specifically collective depression and epidemical suicide. In conclusion, it could be said that Boulding's concept of psychic capital is a striking example of the value of a transdisciplinary approach in the quest for survival.

\section{Declarations}

\section{Acknowledgement}

The author would like to thank anonymous reviewers of the Buletin Psikologi for their constructive criticism during the process of submission.

\section{Funding}

The author received no funding support in the preparation and publication of this article. 


\section{Bostock || Boulding's Psychic Capital}

\section{Author's Contribution}

The present author is the sole author of this article.

Conflict of Interest

There was no conflict of interest in the preparation and publication of this article.

Orcid ID

William Walter Bostock https:/ / orcid.org/0000-0001-7486-7553

\section{References}

Antonovsky, A. (1980). Health, stress and coping. San Francisco, CA, San Francisco : Jossey-Bass Publishers.

APA. (2013). Diagnostic and statistical manual of mental disorders(dsm-5). Aufl. APA-Press.

Artizona, I. D., Berce, D. R., Lupio, R. J., \& Ortiz, C. J. (2019). The phenomenological study of persons deprived of liberty suspected to be suffering from depression: The biopsychosocial coping mechanism. Journal of Social Health, 2, 69-81. http: / / socialhealthjournal.org / wp-content / uploads/2019/09/6.-Artizona-et-al.-Sept-2019.pdf

Bostock, W. W. (2002). Collective mental state and individual agency: Qualitative factors in social science explanation. Qualitative Social Research, 3. https: / / doi.org/http: / /dx.doi.org / 10. 17169 /fqs-3.3.835

Bostock, W. W., \& Smith, G. W. (2001). On measuring national identity. Social Science Paper Publisher, 4 , 1-6. http://eprints.utas.edu.au/788/

Boulding, K. E. (1950). A reconstruction of economics. New York, England: Chapman, Hall, Wiley.

Boulding, K. E. (1966). The economics of the coming spaceship earth. http : / / www . ub . edu / prometheus21/articulos/obsprometheus/BOULDING.pdf

Brewster Smith, M. (1985). The metaphorical basis of selfhood. In A. J. Marsella, G. D. Vos, \& F. L. K. Hsu (Eds.), Culture and self: Asian and western perspectives. New York, London, Tavistock.

CôTé, J. E. (1996). Sociological perspectives on identity formation: The culture identity link and identity capital. Journal of Adolescence, 19, 417-428. https:/ / doi.org/10.1006/jado.1996.0040

Durkheim, E. (1964). The rules of sociological method. New York, NY, Free Press.

Erikson, E. H. (1968). Identity, psychosocial. In D. R. Sills (Ed.), Encyclopedia of the social sciences (pp. 61-65). New York, NY, Macmillan; Free Press.

Eriksson, M., \& Lindström, B. (2006). Antonovsky's sense of coherence scale and the relation with health: A systematic review. Journal of epidemiology \& community health, 60(5), 376-381. https: //doi.org/10.1136/jech.2005.041616

Estellita-Lins, C., Moreno, A. B., Miranda, V., \& Neto, H. R. (2015). About field notes and art: Santa claus suicide. World Cultural Psychiatry Research Review, 10, 298-310. 


\section{Bostock || Boulding's Psychic Capital}

Faturochman. (1999). Collective behaviour and intergroup aggression. Buletin Psikologi, 7(2). https: / / jurnal.ugm.ac.id/buletinpsikologi/article/view/7403

Fauziyyah, A., \& Ampuni, S. (2018). Depression tendencies, social skills, and loneliness among college students in yogyakarta. Jurnal Psikologi, 45(2). https://doi.org/10.22146/jpsi.36324

Freud, S. (1955). Beyond the pleasure principle. In I. J. S. (Ed. \& Trans.) (Eds.), Ed and trans (pp. 1-64). The standard edition of the complete psychological works of Sigmund Freud., The Hogarth Press.(Original Work Published 1920).

Halbwachs, M. (1992). On collective memory. Chicago, IL, University of Chicago Press.

Horvath, A. O. (2000). The therapeutic relationship: From transference to alliance. Journal of Clinical Psychology, 56(2), 163-173. https: / / doi.org / 10.1002 / (sici)1097-4679(200002)56:2<163::aidjclp3>3.0.co;2-d

Huber, F. (2019). Promise me you'll shoot yourself: The mass suicide of ordinary germans in 1945 (Kindle Edition). Melbourne, Australia, Text Publishing.

Huebner, B. (2011). Genuinely collective emotions. European Journal for Philosophy of Science, 1(1). https: //doi.org/10.1007/s13194-010-0006-2

Kesner, L. (2018). Mental ill-health and the epidemiology of representations. Frontiers in Psychiatry, 9(7). https://doi.org/10.3389/fpsyt.2018.00289

Le Bon, G. (2008). The crowd: A study of the popular mind. London, England, Sparkling Books.

Macken, J. (2019). The melancholic torturer: How australia became a nation that tortures refugees. Journal of Sociology, 56(1). https:/ / doi.org/10.1177/1440783319882525

Puri B.K; Laking, I., P.J; Treasaden. (1996). Textbook of psychiatry /b.k. puri, p.j. laking, i.h. treasaden.

Ray, D., Roy, D., Sindhu, B., Sharan, P., \& Banerjee, A. (2017). Neural substrate of group mental health: Insights from multi-brain reference frame in functional neuroimaging. Frontiers in Psychology, 8, 16-27. https://doi.org/10.3389/fpsyg.2017.01627

Reber, A. S. (1995). The penguin dictionary of psychology (2nd ed.) London, New York, Ringwood, Toronto, Auckland, Penguin.

Szanto, T. (2014). How to share a mind: Reconsidering the group mind thesis. Phenomenology and the Cognitive Sciences, 13(1). https:/ / doi.org/10.1007/s11097-013-9323-1

Tajfel, H., Turner, J. C., Austin, W. G., \& Worchel, S. (1979). An integrative theory of intergroup conflict. In M. J. Hatch \& M. Schultz (Eds.), Organizational identity: A reader (pp. 56-65). Oxford, England, Oxford University Press.

Tollefsen, D. (2006). The rationality of collective guilt. Midwest Studies in Philosophy, 30(1), 222-239. https://doi.org/10.1111/j.1475-4975.2006.00136.x 